\title{
Uji Validitas Konstruk Skala Religious and Spiritual Struggles
}

\author{
Nurhamidah \\ UIN Syarif Hidayatullah Jakarta, Indonesia \\ nurhamidah.I7@mhs.uinjkt.ac.id
}

\begin{abstract}
Many people face struggles around the religious and spiritual aspects of daily life, as shown by increasingly researches that have been being carried out. The more research develops on these two variables, the more comprehensive, reliable and concise measurement of someone's struggle in term of religion and spirituality through a multiple domain scale are needed. Religious and spiritual struggles occur when some aspects of religious belief, practice or experience become a negative focus so that it is closely related to emotions, concerns, or conflicts. There are six dimensions in religious and spiritual struggles, namely divine, demonic, interpersonal struggle, morality, ultimate meaning, and doubt. The aim of this study is to test the construct validity of Religious and Spiritual Struggles scale. 26 items of the Religious and Spiritual Struggle are tested. I50 college students are participated in this research. By using confirmatory factor analysis and helped by LISREL 8.70 software, the result shows that all dimensions have a fit model and truly measure religious and spiritual struggles even though there is one item in moral dimension that must be dropped.
\end{abstract}

Keywords: Construct Validity; Religious and Spiritual Struggles

\begin{abstract}
Abstrak
Banyak orang mengalami pergulatan seputar aspek religius dan spiritual dalam kehidupan sehari-hari, sebagaimana ditunjukkan oleh penelitian-penelitian yang semakin luas dilakukan. Semakin berkembangnya penelitian terkait dua variabel ini semakin meningkat pula kebutuhan akan pengukuran yang lebih komprehensif, reliabel, dan ringkas tentang perjuangan seseorang dalam hal agama dan spiritualitas melalui skala yang mencakup banyak domain. Religious and spiritual struggles terjadi ketika beberapa aspek kepercayaan, praktik, atau pengalaman religius menjadi fokus negatif sehingga ia terkait erat dengan emosi, kekhawatiran, atau konflik. Terdapat enam dimensi dalam religious and spiritual struggles yaitu divine, demonic, interpersonal struggles, moral, ultimate meaning, dan doubt. Tujuan dari penelitian ini adalah untuk menguji validitas konstruk dari skala Religious and Spiritual Struggles. Terdapat 26 item dalam skala ini. Responden dalam penelitian ini sebanyak I50 mahasiswa. Metode analisis faktor yang digunakan dalam penelitian ini adalah CFA (confirmatory factor analysis) dengan bantuan perangkat lunak LISREL 8.70. Hasilnya, seluruh dimensi memiliki model yang fit dan benar-benar mengukur religious and spiritual struggles meskipun ada satu item pada dimensi moral yang harus di drop.
\end{abstract}

Kata Kunci : Validitas Konstruk; Religious and Spiritual Struggles 


\section{Pendahuluan}

Agama dan spiritualitas merupakan domain utama dalam hidup bagi banyak orang di seluruh dunia. Secara spiritualitas, kita merujuk pada pencarian unsur-unsur kehidupan suci yang dipandang sebagai manifestasi ilahi, baik di dalam maupun di luar konteks agama tertentu. Selama beberapa dekade terakhir, banyak penelitian telah menunjukkan manfaat agama dan spiritual. Misalnya, agama dan spiritual dapat berfungsi sebagai sumber keamanan, kasih sayang dan kenyamanan (Exline, Yali, \& Sanderson, 2000) atau fasilitator kontrol diri (Mc-Cullough \& Willoughby, 2009).

Banyak orang mengalami pergulatan di sekitar agama dan spiritualitas. Perjuangan dalam hal agama dan spiritual menunjukkan hubungan yang konsisten dengan kesulitan di bidang kesehatan mental dan kesejahteraan (Pargament, 2007). Sampai saat ini, ada beberapa penelitian pengukuran yang menjadikan perjuangan (struggles) dalam agama dan spiritual sebagai fokus utama. Dewasa ini, pengukuran yang lebih komprehensif, reliabel, dan ringkas dari berbagai domain perjuangan (struggles) sangat dibutuhkan.

Di Indonesia, penulis belum menemukan penelitian tentang alat ukur yang menggabungkan dua variabel ini dan dikaitkan dengan perjuangan (struggles). Alat ukur Religious and Spiritual Struggles yang telah ada adalah yang dikonstruk dan diujikan pada orang dewasa Amerika Serikat dari Amazon’s Mechanical Turk (MTurk) (Exline, et al., 2014) yang menggunakan bahasa dan budaya yang berbeda dengan masyarakat Timur, terutama masyarakat Indonesia. Hal inilah yang menjadi alasan penulis melakukan penelitian adaptasi alat ukur ini.

\section{Dasar Teori}

Tokoh yang pertama mempublikasikan konstruk religious and spiritual struggles adalah Julie J. Exline, Kenneth I. Pargament, Joshua B. Grubbs, dan Ann Marie Yali, masing-masing dari Case Western Reserve University, Bowling Green State University, Case Western Reserve University, dan City College of New York. Empat orang ini pengonstruk pertama yang mengombinasikan variabel religius dan spiritual dengan melihat perjuangan responden dalam kedua hal tersebut.

Religius and spiritual struggles terdiri dari dua variabel yaitu religiusitas dan spiritualitas. Religiusitas diartikan sebagai suatu bentuk keberagamaan pada diri individu dikarenakan adanya internalisasi/penanaman nilai-nilai agama ke dalam diri seseorang (Gufron, 20I I). Sedangkan spiritualitas digambarkan sebagai sesuatu yang berkaitan dengan emosi, sikap, maupun perilaku tertentu dari individu. Spiritualitas merupakan suatu bentuk hubungan personal seseorang atau individu terhadap sosok transeden. Spiritualitas mencakup kehidupan dalam batin individu, baik idealisme, sikap, pemikiran, perasaan maupun pengharapan yang mutlak (Tischler, 2002).

Perjuangan agama dan spiritual (religious and spiritual struggles) terjadi ketika beberapa aspek keyakinan, praktik atau pengalaman beragama dan spiritual menjadi fokus dari pikiran atau emosi negatif, keprihatinan atau konflik. Perjuangan (struggle) dalam hal agama dan spiritual dapat berupa banyak hal (Pargament, 2007).

Perjuangan Ilahi (divine struggle) (Pargament et al., 2005) yang melibatkan emosi negatif atau konflik yang berpusat pada hubungan yang dirasakan dengan Tuhan dan kepercayaan tentang yang dituhankan. Perjuangan setan (demonic struggle) melibatkan kekhawatiran bahwa iblis atau roh jahat sedang menyerang seseorang atau menyebabkan peristiwa negatif. Perjuangan antarpribadi (interpersonal struggle) (Pargament et al., 2005) melibatkan pengalaman negatif dengan orang atau lembaga agama atau konflik dengan orang lain di sekitar masalah agama. Perjuangan agama dan spiritual lainnya adalah intrapersonal (Pargament et al., 2005) yang berfokus pada pikiran atau tindakan seseorang. Tiga jenis perjuangan intrapersonal yang menarik di sini adalah; Yang pertama melibatkan perjuangan moral (moral struggle), dimana seseorang bergulat dengan upaya untuk mengikuti prinsip-prinsip moral atau merasa sangat bersalah dalam menanggapi pelanggaran yang dirasakan. Kedua, perjuangan terkait keraguan (doubt struggle), dimana orang-orang terganggu oleh keraguan 
atau pertanyaan tentang keyakinan agama dan spiritual mereka, dan perjuangan ultimate meaning (ultimate meaning struggle), dimana keprihatinan berpusat pada kurangnya makna mendalam yang dirasakan dalam kehidupan.

Banyak literatur yang menghubungkan perjuangan agama dan spiritualitas (religious and spiritual struggles) dengan tekanan emosional dan kesehatan fisik yang buruk (Ano \& Vasconcelles, 2005). Banyak penelitian telah mendokumentasikan hubungan antara perjuangan agama dan spiritual dengan tekanan emosional (Bryant \& Astin, 2008; Ellison \& Lee, 2010), termasuk gejala depresi (Ano \& Vasconcelles, 2005), kecemasan dan tanda-tanda gangguan emosional lainnya (McConnell et al., 2006), dan ide bunuh diri (Exline et al., 2000). Meskipun sebagian besar penelitian bersifat cross sectional, hasil penelitian longitudinal menunjukkan bahwa perjuangan agama dan spiritual memprediksi peningkatan gejala depresi (Park, Brooks, \& Sussman, 2009), tingkat kematian yang lebih tinggi (Pargament, Koenig, Tarakeshwar, \& Hahn, 200I). Secara keseluruhan, temuan-temuan ini menyoroti relevansi klinis perjuangan keagamaan dan spiritual.

\section{Deskripsi Instrumen}

Alat ukur untuk variabel psikologis religious and spiritual struggles yang penulis gunakan adalah alat ukur/skala model Likert. Menurut Saifuddin Azwar (2012), skala model Likert dicirikan dengan adanya stimulasi dalam bentuk pernyataan. Skala model ini digunakan untuk mengukur sikap, pendapat, dan persepsi seseorang atau sekelompok orang mengenai fenomena sosial.

Format respon item model Likert bergradasi dari sangat positif hingga sangat negatif. Penulis menggunakan empat alternatif pilihan respon dalam penelitian ini yang meliputi sangat setuju (SS), setuju (S), tidak setuju (TS), dan sangat tidak setuju (STS). Penulis menghilangkan respon tengah karena menurut Saifuddin Azwar (2012) respon tengah atau netral akan cenderung menggiring responden menempatkan diri pada pilihan tersebut yang kemudian dapat menyebabkan kurang informatifnya data mengenai perbedaan responden.

Skor untuk masing-masing respon yang dipilih yaitu untuk pernyataan favorable mempunyai skor 4, 3, 2 , dan I sedangkan pernyataan yang sifatnya unfavorable adalah kebalikannya yaitu I, 2, 3, dan 4. Seperti yang tercantum pada tabel berikut:

Tabel I. Skor Skala Religious and Spiritual Struggles

\begin{tabular}{lllll}
\hline Pernyataan & SS & S & TS & STS \\
\hline Favorable & 4 & 3 & 2 & I \\
Unfavorable & I & 2 & 3 & 4 \\
\hline
\end{tabular}

Agar memudahkan proses adapatasi dan pengembangan instrumen maka diperlukan blueprint yang berisi informasi mengenai dimensi, indikator, dan posisi serta jumlah item penelitian sebagai gambaran konten dan kawasan ukur yang dapat dijadikan sebagai bahan acuan dalam mengadaptasi dan memodifikasi item.

Tabel 2. Blueprint Skala Religious and Spiritual Struggles

\begin{tabular}{llll}
\hline Dimensi & Nomor Item & Jumlah \\
\cline { 2 - 3 } Divine & Favorable & Unfavorable & \\
Demonic & I, 2, 3, 4, 5 & - & 4 \\
Interpersonal & $6,7,8,9$ & - & 5 \\
Moral & I0, II, I2, I3, I4 & - & 4 \\
Ultimate Meaning & I5, I6, I7, I8 & - & 4 \\
Doubt & I9, 20, 21, 22 & - & 4 \\
Jumlah & $23,24,25,26$ & - & 26 \\
\hline
\end{tabular}


Contoh item masing-masing dimensi dari variabel religious and spiritual struggles dapat dilihat pada tabel berikut:

Tabel 3. Contoh Item Skala Religious and Spiritual Struggles

\begin{tabular}{lll}
\hline Dimensi & Nomor Aitem & Unfavorable \\
\cline { 2 - 3 } Divine & Favorable & - \\
Demonic & Saya merasa seakan-akan Tuhan mengecawakan saya & - \\
Interpersonal & Saya merasa disiksa oleh setan/roh jahat & - \\
& Saya merasa terintimidasi oleh orang yang & - \\
Moral & religius/spiritual & - \\
Ultimate Meaning & Saya berjuang untuk mengikuti prinsip moral saya & - \\
Doubt & Saya meragukan apakah hidup benar-benar berarti & - \\
& Saya berusaha membuktikan apa yang benar-benar saya & - \\
\hline
\end{tabular}

Dari tabel 3 di atas diperoleh informasi bahwa skala religious and spiritual struggles memiliki enam dimensi yang diturunkan ke 26 item pernyataan. Sesuai dengan artikel sebagai landasan penulis dalam mengadaptasi skala yang berjudul The Religious and Spiritual Struggles, kesemua itemnya adalah item favourable. Penulis berusaha memahami per-item dan mencocokkannya dengan dimensi masing-masing serta berusaha memahami apa yang tertera di artikel rujukan, penulis tidak menemukan dijelaskan terdapat item yang unfavorable.

\section{Metode}

\section{Responden}

Responden pada penelitian ini adalah Mahasiswa Jurusan Psikologi Islam UIN Imam Bonjol Padang sebanyak I50 orang yang berada pada tahap perkembangan dewasa awal.

\section{Analisis Data}

Uji validitas konstruk skala Religious and Spiritual Struggles dilakukan dengan menggunakan metode confirmatory factor analysis (CFA). Pengujian analisis CFA dilakukan dengan menggunakan software LISREL 8.70 (Joreskog dan Sorbom, 1999).

Logika CFA menurut Jahja Umar (2012):

I. Terdapat sebuah konsep atau trait yang didefenisikan secara operasional sehingga dapat disusun pertanyaan atau pernyataan untuk mengukurnya. Trait ini disebut faktor, sedangkan pengukuran terhadap faktor ini dilakukan melalui analisis terhadap respon atas item-itemnya.

2. Diteorikan setiap item hanya mengukur satu faktor saja, artinya baik item maupun subskala bersifat unidimensional.

3. Dengan data yang tersedia dapat digunakan untuk mengestimasi matriks korelasi antar item yang seharusnya diperoleh jika memang unidimensional. Matriks korelasi ini disebut sigma $\left(\sum\right)$, kemudian dibandingkan dengan matriks dari data empiris, yang disebut matrik S. Jika teori tersebut benar (unidimenisonal) maka tentunya tidak ada perbedaan antara matriks $\mathrm{S}-\sum$ atau bisa juga dinyatakan dengan $\mathrm{S}-\sum=0$.

4. Pernyataan tersebut dijadikan hipotesis nihil yang kemudian diuji dengan chi-square. Jika hasil tidak signifikan $p$-value $>0.05$, maka hipotesis nihil tersebut tidak ditolak. Artinya, teori unidimensionalitas tersebut dapat diterima bahwa item hanya mengukur satu faktor saja. 
5. Jika model fit, maka langkah selanjutnya menguji apakah item signifikan atau tidak mengukur apa yang hendak diukur, dengan menggunakan t-test. Jika hasil t-test tidak signifikan (sig. $<1.96)$ maka item tersebut tidak signifikan dalam mengukur apa yang hendak diukur, bila perlu item yang demikian dieliminasi.

6. Selanjutnya apabila dari CFA terdapat item yang koefisien muatan faktornya negatif, maka item tersebut harus dieliminasi. Berarti item tersebut mengukur hal yang berlawanan dengan apa yang hendak diukur. Namun demikian perlu diperiksa kembali apakah item tersebut berupa item negatif (unfavourable) untuk item yang unfavourable sebelum analisis CFA dilakukan.

\section{Hasil dan Pembahasan}

\section{Divine}

Dimensi divine yang terdiri dari lima item diuji dengan analisis CFA model satu faktor, apakah benar bersifat unidimensional atau tidak. Dari hasil analisis diperoleh bahwa model tidak fit. Hasil uji pertama, ChiSquare $=3 \mathrm{I} .6 \mathrm{I}, \mathrm{df}=5, P_{\text {-value }}=0.0000 \mathrm{I}, \mathrm{RMSEA}=0.189$. Karena model tidak fit dengan data, dilakukan modifikasi terhadap model dengan cara membebaskan kesalahan pengukuran pada beberapa item untuk saling berkorelasi. Hasilnya diperoleh model yang fit dengan data. Hasil uji setelah model dimodifikasi, ChiSquare $=7.29, \mathrm{df}=3, P_{\text {-value }}=0.063 \mathrm{I} 3, \mathrm{RMSEA}=0.098$.

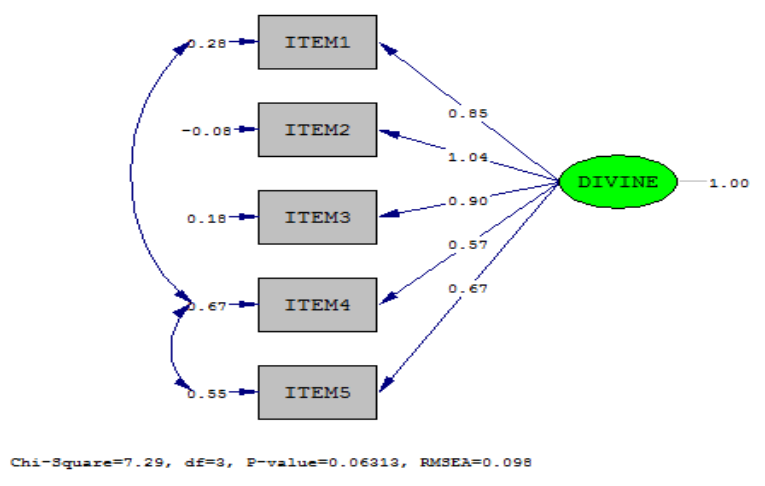

Gambar I Path Diagram Divine

Berdasarkan hasil analisis yang tertera pada path diagram di atas diperoleh $P$-value $>0.05$, nilai ini memenuhi kriteria model satu faktor dapat diterima sehingga disimpulkan lima item ini hanya mengukur divine. Selanjutnya penulis melihat nilai t pada masing-masing koefisien muatan faktor untuk mengetahui apakah lima item ini mengukur divine secara signifikan atau tidak, selain itu hal ini juga untuk menentukan apakah ada item yang perlu dieliminasi atau tidak. Informasinya tertera dalam tabel 4 berikut:

Tabel 4. Muatan Faktor Dimensi Divine

\begin{tabular}{llllll}
\hline Dimensi & $\begin{array}{l}\text { Nomor } \\
\text { Item }\end{array}$ & Lamda & $\begin{array}{l}\text { Standar } \\
\text { Error }\end{array}$ & t-value & Keterangan \\
& I & 0.85 & 0.07 & 13.03 & Valid \\
\hline \multirow{4}{*}{ Divine } & 2 & 1.04 & 0.06 & 18.72 & Valid \\
& 3 & 0.90 & 0.06 & 14.32 & Valid \\
& 4 & 0.57 & 0.07 & 8.00 & Valid \\
& 5 & 0.67 & 0.07 & 9.60 & Valid \\
\hline
\end{tabular}


Sebagaimana tertera di tabel 4, nilai t lebih besar dari I.96 ( $\mathrm{t}>\mathrm{I} .96$ ) untuk masing-masing koefisien muatan faktor dan tidak terdapat item yang muatan faktornya negatif. Disimpulkan bahwa lima item pada dimensi divine semuanya valid atau benar-benar mengukur apa yang ingin diukur secara signifikan.

\section{Demonic}

Dimensi demonic yang terdiri dari empat item diuji dengan analisis CFA model satu faktor, apakah benar bersifat unidimensional atau tidak. Dari hasil analisis diperoleh bahwa model tidak fit. Hasil uji pertama, ChiSquare $=1.62, \mathrm{df}=2, P_{\text {-value }}=0.4448 \mathrm{I}, \mathrm{RMSEA}=0.000$. Karena model tidak fit dengan data, dilakukan modifikasi terhadap model dengan cara membebaskan kesalahan pengukuran pada beberapa item untuk saling berkorelasi. Hasilnya diperoleh model yang fit dengan data. Hasil uji setelah model dimodifikasi, ChiSquare $=0.19, \mathrm{df}=\mathrm{I}, P_{\text {-value }}=0.66266$, $\mathrm{RMSEA}=0.000$.

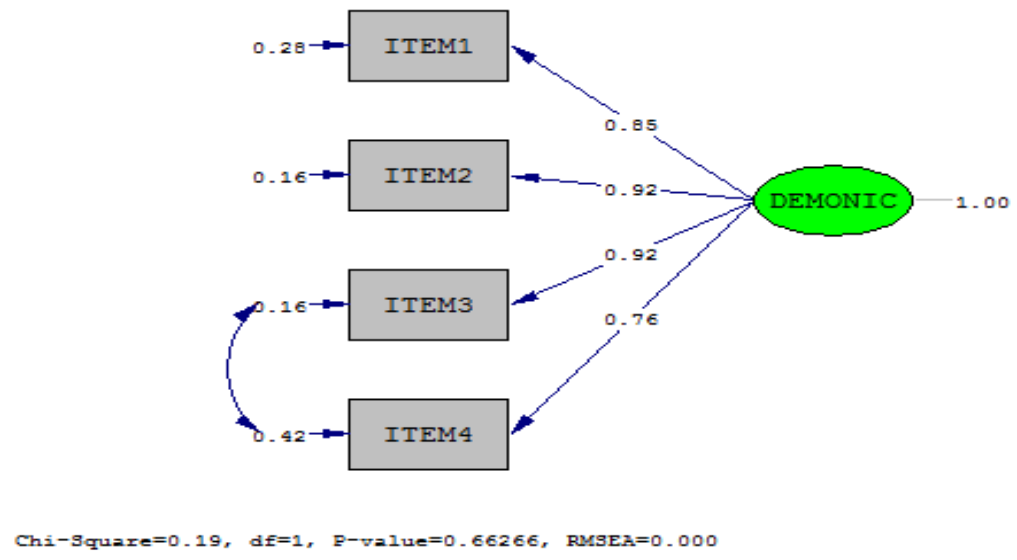

Gambar 2 Path Diagram Demonic

Berdasarkan hasil analisis yang tertera pada path diagram di atas diperoleh $P$-value $>0.05$, nilai ini memenuhi kriteria model satu faktor dapat diterima sehingga disimpulkan empat item ini hanya mengukur demonic. Selanjutnya penulis melihat nilai t pada masing-masing koefisien muatan faktor untuk mengetahui apakah empat item ini mengukur demonic secara signifikan atau tidak, selain itu hal ini juga untuk menentukan apakah ada item yang perlu dieliminasi atau tidak. Informasinya tertera dalam tabel 5 berikut:

Tabel 5. Muatan Faktor Dimensi Demonic

\begin{tabular}{llllll}
\hline Dimensi & Nomor Item & Lamda & $\begin{array}{l}\text { Standar } \\
\text { Error }\end{array}$ & t-value & Keterangan \\
\hline \multirow{3}{*}{ Demonic } & I & 0.85 & 0.07 & I2.62 & Valid \\
& 2 & 0.92 & 0.06 & I4.30 & Valid \\
& 3 & 0.92 & 0.06 & 14.25 & Valid \\
& 4 & 0.76 & 0.07 & I0.5I & Valid \\
\hline
\end{tabular}

Sebagaimana tertera di tabel 5, nilai t lebih besar dari I.96 ( $\mathrm{t}>$ I.96) untuk masing-masing koefisien muatan faktor dan tidak terdapat item yang muatan faktornya negatif. Disimpulkan bahwa empat item pada dimensi demonic semuanya valid atau benar-benar mengukur apa yang ingin diukur secara signifikan. 


\section{Interpersonal Struggles}

Dimensi interpersonal struggles yang terdiri dari lima item diuji dengan analisis CFA model satu faktor, apakah benar bersifat unidimensional atau tidak. Dari hasil analisis diperoleh bahwa model tidak fit. Hasil uji pertama, Chi-Square $=91.68, \mathrm{df}=5, P$-value $=0.00000, \mathrm{RMSEA}=0.34 \mathrm{I}$. Karena model tidak fit dengan data, dilakukan modifikasi terhadap model dengan cara membebaskan kesalahan pengukuran pada beberapa item untuk saling berkorelasi. Hasilnya diperoleh model yang fit dengan data. Hasil uji setelah model dimodifikasi, Chi-Square $=3.84, \mathrm{df}=3, P_{\text {-value }}=0.27890, \mathrm{RMSEA}=0.043$.

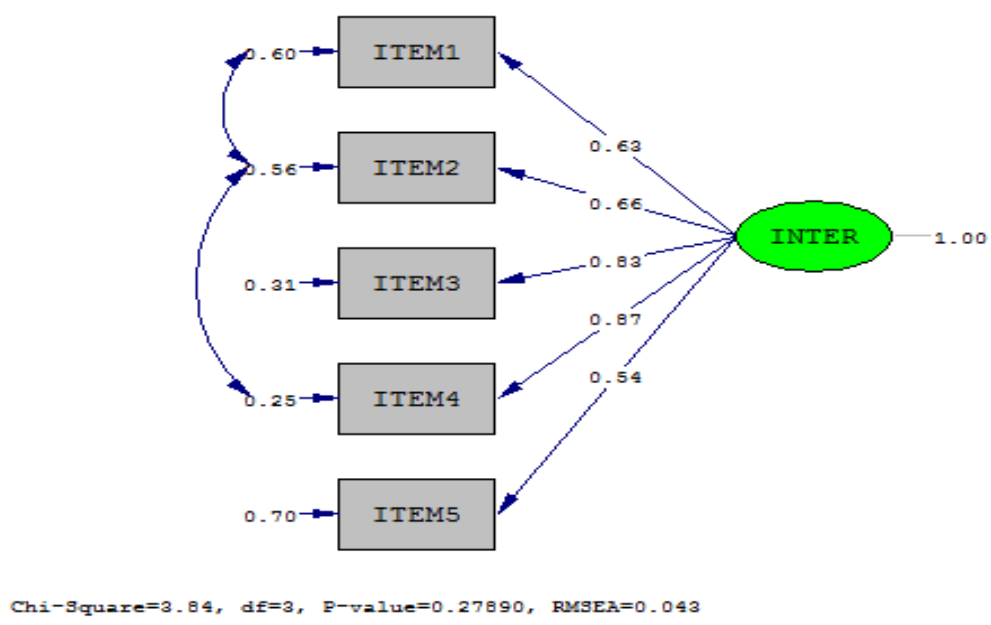

Gambar 3 Path Diagram Interpersonal Struggles

Berdasarkan hasil analisis yang tertera pada path diagram di atas diperoleh $P$-value $>0.05$, nilai ini memenuhi kriteria model satu faktor dapat diterima sehingga disimpulkan lima item ini hanya mengukur interpersonal struggles. Selanjutnya penulis melihat nilai t pada masing-masing koefisien muatan faktor untuk mengetahui apakah lima item ini mengukur interpersonal struggles secara signifikan atau tidak, selain itu hal ini juga untuk menentukan apakah ada item yang perlu dieliminasi atau tidak. Informasinya tertera dalam tabel 6 berikut:

Tabel 6. Muatan Faktor Dimensi Interpersonal Struggles

\begin{tabular}{llllll}
\hline Dimensi & Nomor Item & Lamda & Standar Error & t-value & Keterangan \\
\hline \multirow{3}{*}{ Interpersonal } & $\mathrm{I}$ & 0.63 & 0.08 & 8.07 & Valid \\
Struggles & 2 & 0.66 & 0.08 & 8.19 & Valid \\
& 3 & 0.83 & 0.07 & II.35 & Valid \\
& 4 & 0.87 & 0.07 & II.99 & Valid \\
& 5 & 0.54 & 0.08 & 6.79 & Valid \\
\hline
\end{tabular}

Sebagaimana tertera di tabel 6, nilai t lebih besar dari I.96 ( $\mathrm{t}>\mathrm{I} .96$ ) untuk masing-masing koefisien muatan faktor dan tidak terdapat item yang muatan faktornya negatif. Disimpulkan bahwa lima item pada dimensi interpersonal struggles semuanya valid atau benar-benar mengukur apa yang ingin diukur secara signifikan.

\section{Moral}

Dimensi moral yang terdiri dari empat item diuji dengan analisis CFA model satu faktor, apakah benar bersifat unidimensional atau tidak. Dari hasil analisis diperoleh bahwa model tidak fit. Hasil uji pertama, Chi- 
Square $=15.60, \mathrm{df}=2, P_{\text {-value }}=0.0004 \mathrm{I}, \mathrm{RMSEA}=0.2 \mathrm{I}$. Karena model tidak fit dengan data, dilakukan modifikasi terhadap model dengan cara membebaskan kesalahan pengukuran pada beberapa item untuk saling berkorelasi. Hasilnya diperoleh model yang fit dengan data. Hasil uji setelah model dimodifikasi, ChiSquare $=0.00, \mathrm{df}=0, P_{\text {-value }}=1.00000$, dan $\mathrm{RMSEA}=0.000$.

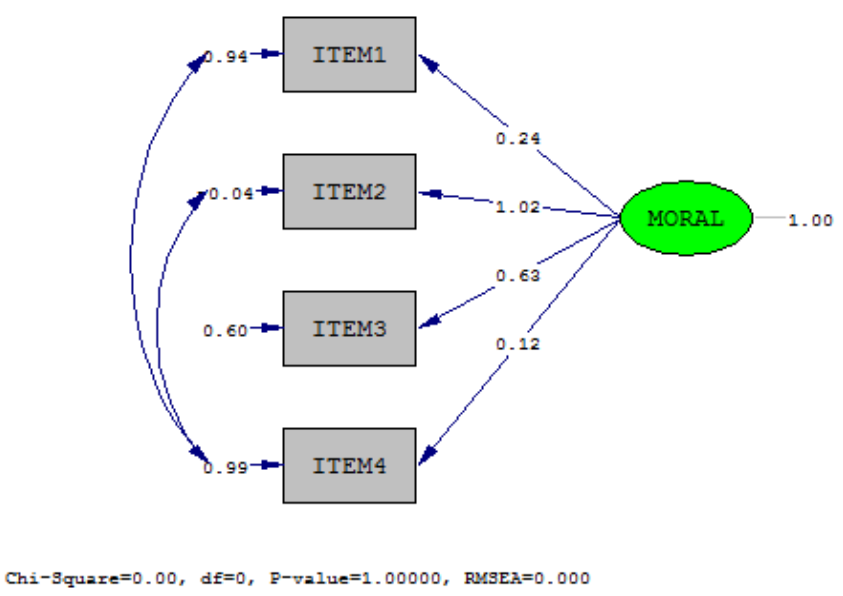

Gambar 4. Path Diagram Moral

Berdasarkan hasil analisis yang tertera pada path diagram di atas diperoleh $P$-value $>0.05$, nilai ini memenuhi kriteria model satu faktor dapat diterima sehingga disimpulkan empat item ini hanya mengukur moral. Selanjutnya penulis melihat nilai t pada masing-masing koefisien muatan faktor untuk mengetahui apakah empat item ini mengukur interpersonal struggles secara signifikan atau tidak, selain itu hal ini juga untuk menentukan apakah ada item yang perlu dieliminasi atau tidak. Informasinya tertera dalam tabel 7 berikut:

Tabel 7. Muatan Faktor Dimensi Moral

\begin{tabular}{llllll}
\hline Dimensi & Nomor Item & Lamda & Standar Error & t-value & Keterangan \\
\hline \multirow{3}{*}{ Moral } & I & 0.24 & 0.09 & 2.55 & Valid \\
& 2 & 1.02 & $0.2 \mathrm{I}$ & $4.8 \mathrm{I}$ & Valid \\
& 3 & 0.63 & 0.15 & 4.32 & Valid \\
& 4 & 0.12 & 0.12 & 0.96 & Tidak Valid \\
\hline
\end{tabular}

Karena item keempat dari dimensi moral t-valuenya kurang dari I.96 (hanya 0.96) maka item tersebut tidak valid sehingga item tersebut dieliminasi. Penulis melakukan analisis kembali dengan tiga item untuk dimensi moral. Diperoleh hasil dengan model yang tetap fit dan tiga item yang valid. Informasinya sebagai berikut. 


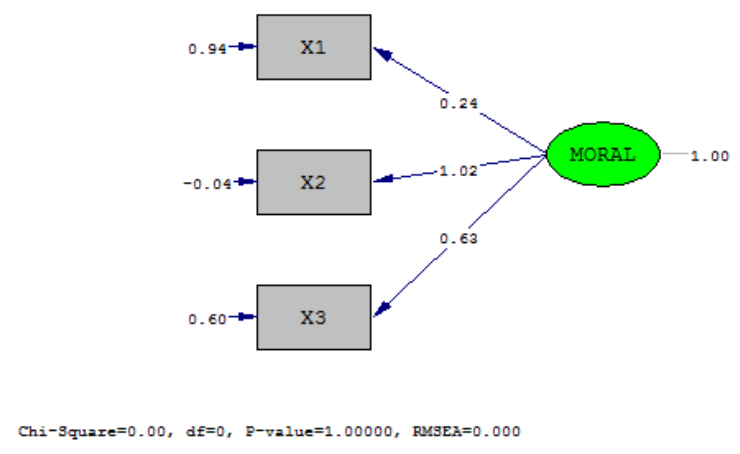

Gambar 5. Path Diagram Moral (3 Item)

Berdasarkan hasil analisis yang tertera pada path diagram di atas diperoleh nilai $p$-value $>0.05$ sehingga bisa disimpulkan bahwa model dengan satu faktor bisa diterima. Hal ini berarti bahwa seluruh item hanya mengukur satu faktor yaitu moral. Selain itu, yang perlu diperhatikan adalah apakah item-item tersebut mengukur faktor yang hendak diukur secara signifikan sekaligus menentukan apakah ada item yang perlu dieliminasi atau tidak. Pengujiannya dilakukan dengan melihat nilai t bagi setiap koefisien muatan faktor, sebagaimana tertera dalam tabel 8 berikut:

Tabel 8. Muatan Faktor Dimensi Moral (3 Item)

\begin{tabular}{llllll}
\hline Dimensi & Nomor Aitem & Lamda & Standar Error & t-value & Keterangan \\
\hline \multirow{3}{*}{ Moral } & I & 0.24 & 0.09 & 2.55 & Valid \\
& 2 & 1.02 & $0.2 \mathrm{I}$ & $4.8 \mathrm{I}$ & Valid \\
& 3 & 0.63 & 0.15 & 4.32 & Valid \\
\hline
\end{tabular}

Sebagaimana tertera di tabel 8, nilai t lebih besar dari I.96 ( $\mathrm{t}>\mathrm{I} .96$ ) untuk masing-masing koefisien muatan faktor dan tidak terdapat item yang muatan faktornya negatif. Disimpulkan bahwa tiga item pada dimensi moral semuanya valid atau benar-benar mengukur apa yang ingin diukur secara signifikan.

\section{Ultimate Meaning}

Dimensi ultimate meaning yang terdiri dari empat item diuji dengan analisis CFA model satu faktor, apakah benar bersifat unidimensional atau tidak. Dari hasil analisis diperoleh bahwa model tidak fit. Hasil uji pertama, Chi-Square $=$ I2.I6, $\mathrm{df}=2, P$-value $=0.00220, \mathrm{RMSEA}=0.105$. Karena model tidak fit dengan data, dilakukan modifikasi terhadap model dengan cara membebaskan kesalahan pengukuran pada beberapa item untuk saling berkorelasi. Hasilnya diperoleh model yang fit dengan data. Hasil uji setelah model dimodifikasi, Chi-Square $=0.63, \mathrm{df}=\mathrm{I}, P_{\text {-value }}=0.42794$, RMSE $=0.000$. 


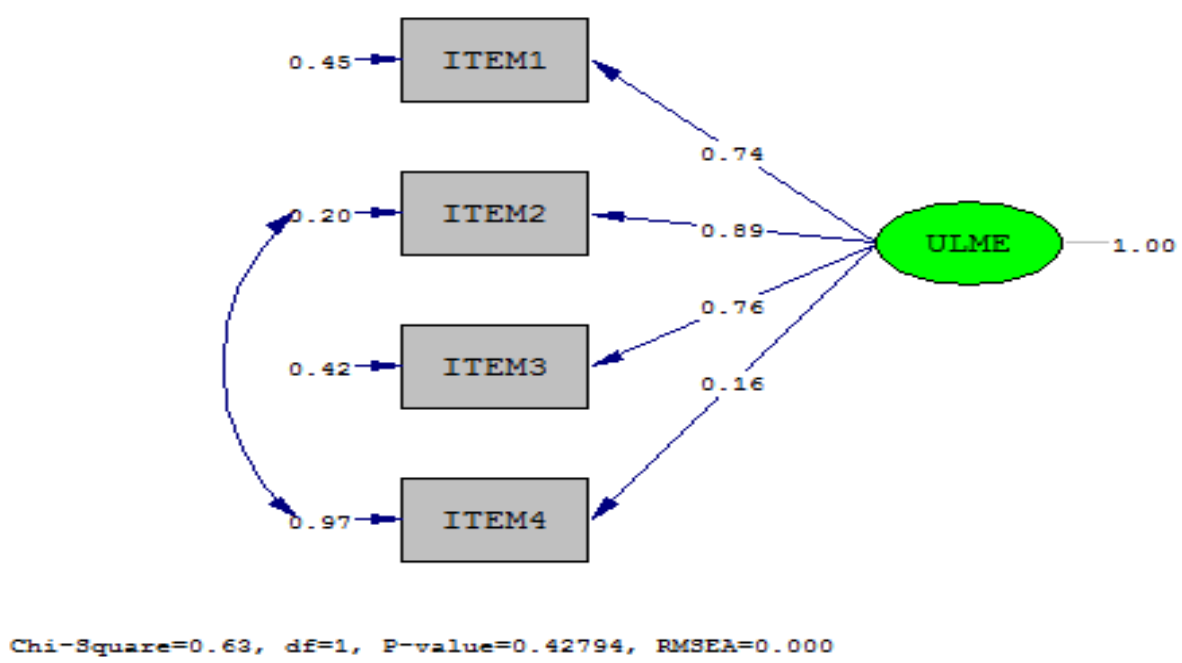

Gambar 6. Path Diagram Ultimate Meaning

Berdasarkan hasil analisis yang tertera pada path diagram di atas diperoleh $P$-value $>0.05$, nilai ini memenuhi kriteria model satu faktor dapat diterima sehingga disimpulkan empat item ini hanya mengukur ultimate meaning. Selanjutnya penulis melihat nilai t pada masing-masing koefisien muatan faktor untuk mengetahui apakah empat item ini mengukur ultimate meaning secara signifikan atau tidak, selain itu hal ini juga untuk menentukan apakah ada item yang perlu dieliminasi atau tidak. Informasinya tertera dalam tabel 9 berikut:

Tabel 9. Muatan Faktor Dimensi Ultimate Meaning

\begin{tabular}{llllll}
\hline Dimensi & Nomor Item & Lamda & Standar Error & t-value & Keterangan \\
\hline \multirow{3}{*}{ Ultimate } & $\mathrm{I}$ & 0.85 & 0.07 & $\mathrm{I} 2.62$ & Valid \\
Meaning & 2 & 0.92 & 0.06 & $\mathrm{I} 4.30$ & Valid \\
& 3 & 0.92 & 0.06 & $\mathrm{I} 4.25$ & Valid \\
& 4 & 0.76 & 0.07 & $\mathrm{I} 0.5 \mathrm{I}$ & Valid \\
\hline
\end{tabular}

Sebagaimana tertera di tabel 9, nilai t lebih besar dari I.96 ( $\mathrm{t}>\mathrm{I} .96$ ) untuk masing-masing koefisien muatan faktor dan tidak terdapat item yang muatan faktornya negatif. Disimpulkan bahwa empat item pada dimensi ultimate meaning semuanya valid atau benar-benar mengukur apa yang ingin diukur secara signifikan.

\section{Doubt}

Dimensi doubt yang terdiri dari empat item diuji dengan analisis CFA model satu faktor, apakah benar bersifat unidimensional atau tidak. Dari hasil analisis diperoleh bahwa model tidak fit. Hasil uji pertama, ChiSquare $=175.60, \mathrm{df}=2, P$-value $=0.00000, \mathrm{RMSEA}=0.763$. Karena model tidak fit dengan data, dilakukan modifikasi terhadap model dengan cara membebaskan kesalahan pengukuran pada beberapa item untuk saling berkorelasi. Hasilnya diperoleh model yang fit dengan data. Hasil uji setelah model dimodifikasi, ChiSquare $=0.17, \mathrm{df}=\mathrm{I}, P_{\text {-value }}=0.67777$, RMSE $=0.000$. 


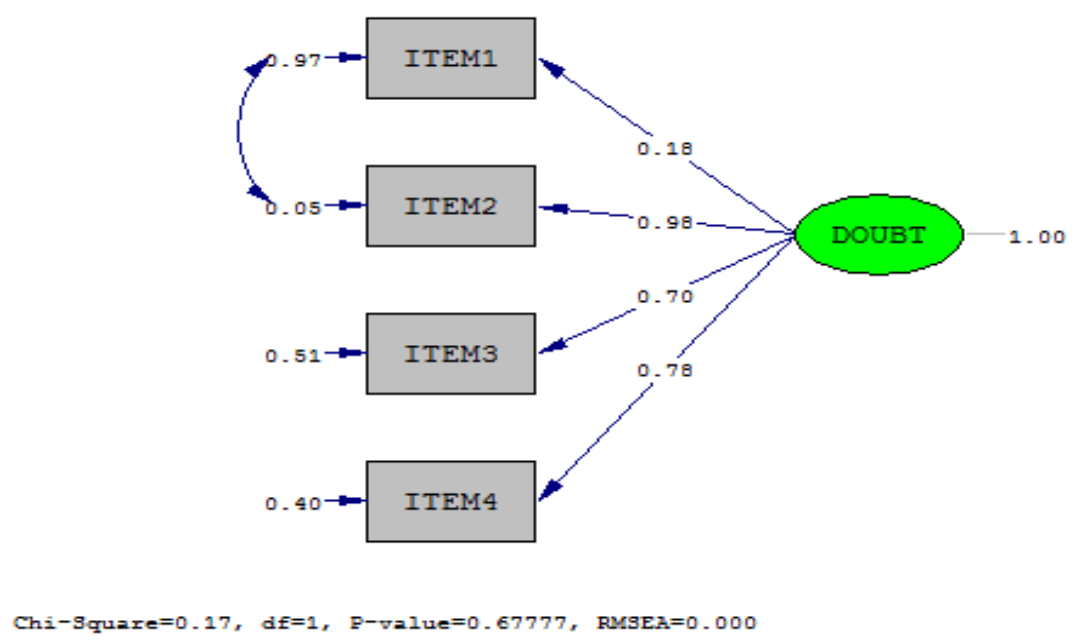

Gambar 7. Path Diagram Doubt

Berdasarkan hasil analisis yang tertera pada path diagram di atas diperoleh $P$-value $>0.05$, nilai ini memenuhi kriteria model satu faktor dapat diterima sehingga disimpulkan empat item ini hanya mengukur doubt. Selanjutnya penulis melihat nilai t pada masing-masing koefisien muatan faktor untuk mengetahui apakah empat item ini mengukur doubt secara signifikan atau tidak, selain itu hal ini juga untuk menentukan apakah ada item yang perlu dieliminasi atau tidak. Informasinya tertera dalam tabel IO berikut.

Tabel I0. Muatan Faktor Dimensi Doubt

\begin{tabular}{llllll}
\hline Dimensi & Nomor Item & Lamda & Standar Error & t-value & Keterangan \\
\hline \multirow{3}{*}{ Doubt } & I & 0.18 & 0.08 & 2.28 & Valid \\
& 2 & 0.98 & $0.1 \mathrm{I}$ & 9.13 & Valid \\
& 3 & 0.70 & 0.08 & $9.2 \mathrm{I}$ & Valid \\
& 4 & 0.78 & 0.08 & 9.15 & Valid \\
\hline
\end{tabular}

Sebagaimana tertera di tabel I0, nilai t lebih besar dari I.96 ( $\mathrm{t}>$ I.96) untuk masing-masing koefisien muatan faktor dan tidak terdapat item yang muatan faktornya negatif. Disimpulkan bahwa empat item pada dimensi doubt semuanya valid atau benar-benar mengukur apa yang ingin diukur secara signifikan.

\section{Penutup}

Hasil uji validitas konstruk terhadap skala Religious and Spiritual Struggles yang terdiri dari 26 item menunjukkan bahwa 25 item memenuhi kriteria item yang baik dan bersifat unidimensional. Artinya itemitem ini mengukur satu faktor saja yaitu religious and spiritual struggles. Tiga kriteria item yang baik adalah item tersebut memiliki muatan faktor positif, item tersebut valid (signifikan, t>1.96 atau $\mathrm{t}<-$ I.96), dan item tersebut harus memiliki korelasi antar kesalahan pengukuran yang tidak lebih dari tiga.

Dengan menggunakan pendekatan confirmatory factor analysis (CFA) diperoleh hasil 25 dari 26 item valid mengukur religious and spiritual struggle. Atas dasar ini maka model satu faktor pada seluruh item yang diteorikan oleh Religious and Spiritual Struggles Scale dapat diterima, kecuali satu item pada dimensi moral yang harus dibuang karena tidak valid disebabkan t-valuenya tidak lebih besar dari I.96 dan tidak lebih kecil dari -I.96. 


\section{Daftar Pustaka}

Ano, G. G., \& Vasconcelles, E. B. (2005). Religious coping and psychological adjustment to stress: A metaanalysis. Journal of Clinical Psychology, 6I, 46I-480. doi:I0.1002/jclp.20049

Azwar, S. (2012). Penyusunan Skala Psikologi. Yogyakarta: Pustaka Pelajar.

Bryant, A. N., \& Astin, H. S. (2008). The correlates of spiritual struggle during the college years. Journal of Higher Education, 79, I-27. doi: I0.1353/jhe.2008.0000

Ellison, C. G., \& Lee, J. (2010). Spiritual struggles and psychological distress: Is there a dark side of religion? Social Indicators Research, 98, 50I-5I7. doi:I0.1007/sI I205-009-9553-3

Exline, J. J., Yali, A. M., \& Sanderson, W. C. (2000). Guilt, discord, and alienation: The role of religious strain in depression and suicidality. Journal of Clinical Psychology, 56, I48I-I496. doi:I0.I002/I097-4679(2000I2)56:I2_I48I::AID-I_3.0.CO;2-A

Exline, J.J., Pargament, K.I., Grubbs, J.B., Yali, A.M. (20I4). The religious and spiritual struggles scale: Development and initial validations. Psychology of Religion and Spirituality. 6 (3): 208-222.

Ghufron, N., \& Risnawati, R.S. (20II). Teori-teori Psikologi. Jakarta: Ar-Ruzz Media.

McConnell, K. M., Pargament, K. I., Ellison, C. G., \& Flannelly, K. J. (2006). Examining the links between spiritual struggles and symptoms of psychopathology in a national sample. Journal of Clinical Psychology, 62, I469-I484. doi:10.1002/jclp.20325

McCullough, M. E., \& Willoughby, B. L. B. (2009). Religion, self-regulation, and self-control: Associations, explanations, and implications. Psychological Bulletin, 135, 69-93. doi:I0.1037/a00I42I3

Pargament, K. I. (2007). Spiritually integrated psychotherapy: Understanding and addressing the sacred. New York: Guilford Press.

Pargament, K. I., Murray-Swank, N., Magyar, G. M., \& Ano, G. G. (2005). Spiritual struggle: A phenomenon of interest to psychology and religion. In W. R. Miller \& H. Delaney (Eds.), Judeo-Christian perspectives on psychology: Human nature, motivation, and change (pp. 245-268). Washington, DC: APA Books. doi:I0.1037/I0859-0I3

Pargament, K. I., Koenig, H. G., Tarakeshwar, N., \& Hahn, J. (200I). Religious struggle as a predictor of mortality among medically ill elderly patients: A two-year longitudinal study. Archives of Internal Medicine, I6I, I88I-I885. doi:I0.I00I/archinte.I6I.I5.I88I

Park, C. L., Brooks, M. A., \& Sussman, J. (2009). Dimensions of religion and spirituality in psychological adjustment of older adults living with congestive heart failure. In A. L. Ai \& M. Ardelt (Eds.), Faith and well-being in later life (pp. 4I-58). Hauppauge, NY: Nova Science.

Tischler, L. (2002). Linking emotional intelligence, spirituality and workplace performance: Defenitions, models, and ideas for research. Journal of Managerial Psychology. I7 (3): 203.

Umar, J. (2012). Confirmatory Factor Analysis (Bahan Ajar Perkuliahan). Jakarta: UIN Syarif Hidayatullah. 